\title{
Evaluation by the Oxidase Activity of Xylotropic Macromycetes Causing White Decay
}

\author{
N. A. Akhundova1,2, S. B. Orucova3 , K. F. Bahshaliyeva',4, P. Z. Muradov², E. A. Rahimovov, \\ ${ }^{1}$ Azerbaijan State Economic University, Baku, Azerbaijan \\ ${ }^{2}$ Institute of Microbiology of the NAS of Azerbaijan, Baku, Azerbaijan \\ ${ }^{3}$ Odlar Yurdu University, Baku, Azerbaijan \\ ${ }^{4}$ Institute of Fruit and Tea-Making, The Ministry of Agriculture of the Republic of Azerbaijan, Baku, Azerbaijan \\ ${ }^{5}$ Lankaran State Universiteti, Lankaran, Azerbaijan \\ Email:mpanah@mail.ru
}

How to cite this paper: Akhundova, N.A., Orucova, S.B., Bahshaliyeva, K.F., Muradov, P.Z. and Rahimov, E.A. (2019) Evaluation by the Oxidase Activity of Xylotropic Macromycetes Causing White Decay. Advances in Bioscience and Biotechnology, 10, 179-187.

https://doi.org/10.4236/abb.2019.107013

Received: May 23, 2019

Accepted: July 19, 2019

Published: July 22, 2019

Copyright $\odot 2019$ by author(s) and Scientific Research Publishing Inc. This work is licensed under the Creative Commons Attribution International License (CC BY 4.0).

http://creativecommons.org/licenses/by/4.0/

\begin{abstract}
In researches, were evaluated 103 strains of 25 species of xylotrophic micromycetes causing white decay which spreads in ecologically different regions of Azerbaijan for the synthesis of phenoloxidases (laccase, peroxidase, and ligninase). It was determined that strains belonging to species such as Cerena unicolar, Pleurotus ostreatus, Schizophyllum commune and Trametes versicolor are more actively synthesized phenoloxidase and this process generally occurs by the inductive way. Despite this, unlike from classic inductive enzymes basal level of phenoloxidases in the basidiomycetes is much higher, which can be characterized as the sign adaptation of xylotroph macromisets to live in woody substrates.
\end{abstract}

\section{Keywords}

Xylotrophic Macromycetes, White Decay, Phenol Oxidase, Unitary Theory

\section{Introduction}

As is known, mushrooms are one of the research objects in the center of special attention, such as biologically active substances, as well as the producer of enzymes which have a different effect [1]. So that, the synthesis of enzymes that catalyzes the degeneration of polymers such as cellulose, lignin, and hemicellulose which form in green biomass resulting from photosynthesis has increase interest to them [2] [3]. In this regard, the studies where an active producer of these enzymes was found, clarified a number of issues of enzyme synthesis [4] [5] and some results have even been applied to the industrial. However, fungi investigated in this direction constitute a small part of those known ones and 
some issues related to the synthesis regulating of some enzymes have not been clarified yet [6] [7] as well as producers with high biological activity is in the minority today.

Mushrooms are a permanent component of every ecosystem where organic matter is present and carry out various functions there, more accurately are active participants of all processes (production, destructions, arrangements, and indications) taking place in the ecosystem [8]. The basis of the use of these mushrooms in practice stays their active participation in these functions [9]. In addition to the variety of functions carried out by mushrooms in nature, the ecological groups that they formed in nature are also characterized by a wide variety and they are some features directed to the practice are related to this grouping. One of the ecological groups of mushrooms is the xylotrophs, which their main habitat and feeding areas are woody plants (trees, as well as a number of shrubs) [2] [5] [10].

Although there is no accurate literature information about the number of xylotrophic macromycetes, can be noted that about 1000 species of mushroom are carried such features. Their main spreads areas are natural and artificial forests [11], green areas, gardens, and parks.

All of the above mentioned are found in the territory of the Republic of Azerbaijan and 212 species of xylotrophic macromycetes have been found in trees and shrubs at these areas [4] [12] [13]. Have been clarified some issues such as about synthesis of hydrolase and oxidase enzymes by some of the mushroom and regulation of synthesis in selected mushroom as an active producer. Be changeable of activity indicators in the level of strain, peculiar to the this or another producer, also takes part of this in a similar situation in the catalytic activity of these enzymes, makes necessary to study those mushroom. Taking this into account, the presented work was devoted to the evaluation of xylotroph macromycetes spread in the nature of Azerbaijan by the activity of enzymes such as phenol oxidase, more accurate laccase, peroxidase, and lignin. In research, the selection only phenoloxidase is related to the fact that, were widely conducted investigations on the study of xylotroph macromycetes which spread in Azerbaijan and compared to them phenoloxidase, especially ligninaza was not subject to special investigation.

\section{Material and Methods}

The research has begun from 2016 and the samples taken for research have covered all major geomorphological units (Greater Caucasus-GC, Kura Araz lowland-KA, Talish Mountains-TM and Small Caucasus-SG) of Azerbaijan (Figure 1).

Taking of sampling, initial passportization, and preparation for laboratory analysis was carried out according to known methods as well as those used in previous studies [4] [13]. Examples from the study areas area were taken from trees and arms only because of their vital shape. Sampling was carried out in accordance with the methods of the route and permanent observation areas $(100 \mathrm{~m} \times 100 \mathrm{~m})$. 


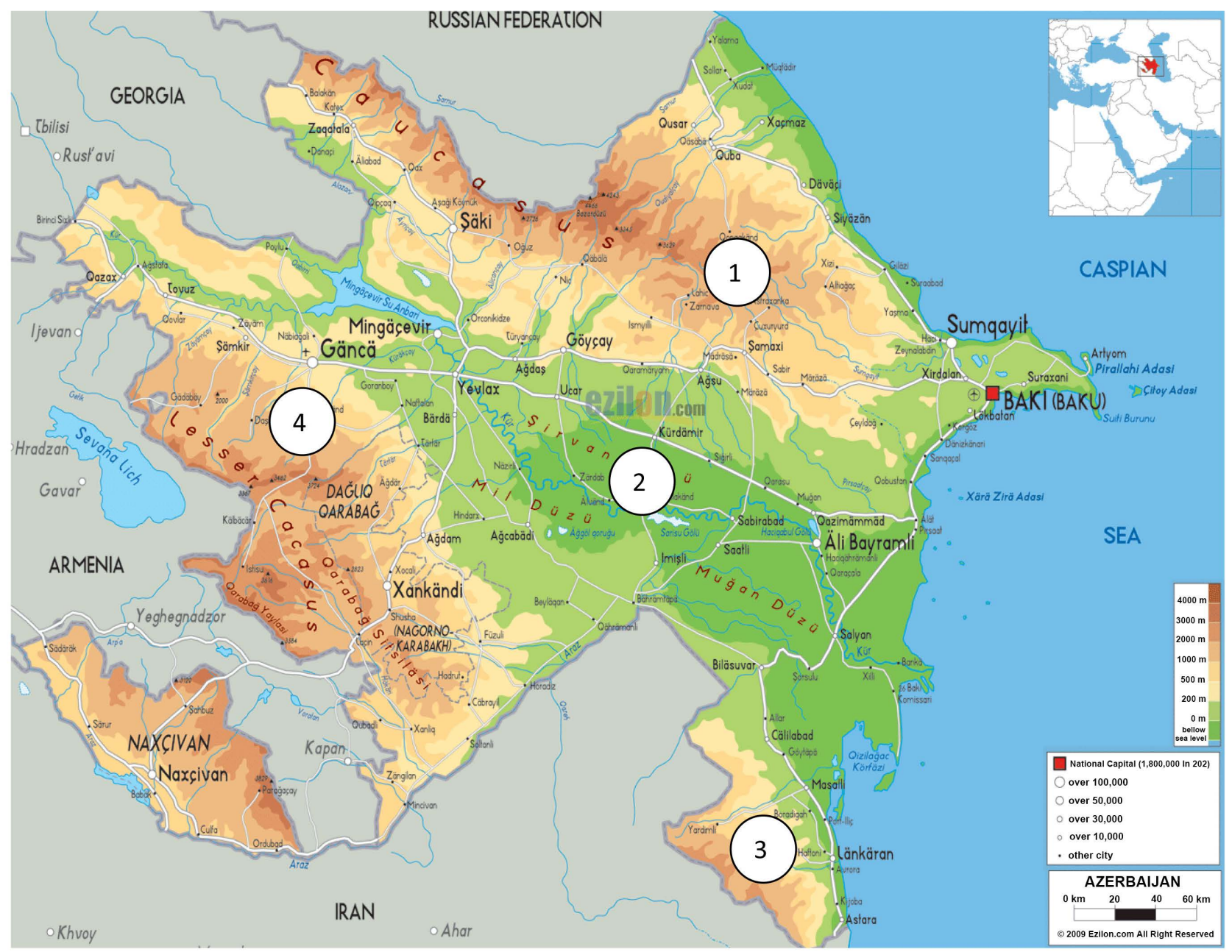

Figure 1. An overview of the surveyed areas. 1-Greater Caucasus; 2-Kura Araz lowland; 3-Talish Mountains and 4-Small Caucasus.

During the identification of mushrooms, the determinant prepared was used based on morphological, culturological, and physiological symptoms of mushrooms [14] [15].

During the cultivation of separated cultures, initial cultivation was carried out in a liquid nutrient medium, which content of the nutrient medium used for this purpose was: glucose-10; peptone $-3 ; \mathrm{NH}_{4} \mathrm{NO}_{3}-1.5 ; \mathrm{NaCl}-0.5 ; \mathrm{MgSO}_{4} \cdot 7 \mathrm{H}_{2} \mathrm{O}$; $\mathrm{K}_{2} \mathrm{HPO}_{3}-0.4 ; \mathrm{FeSO}_{4}$-in small quantities, ordinary water-1 L. Sterilization condition $-0.5 \mathrm{~atm}, 0.5$ hours, acidity of the environment after sterilization 5.5 5.7. As the primary sowing material was used from quadratic particles taken from the colonia of mushroom cultures cultivated in a standard nutrient medium. The biomass obtained in this way is cut into small pieces by using a magnetic mixer is used as a sowing material.

The activity of phenoloxidases was determined by spectrophotometrically way. In the course of the study, to determining the activity of peroxidase and laccase as a substrate uses $1 \%$ hydroxynone solution and the activity of the enzymes is determined by the optical density change in the $240 \mathrm{~nm}$ wavelength 
after adding a cultural solution (CS) to that substrate. When determining peroxidase activity in addition to reaction mixture is added $\mathrm{H}_{2} \mathrm{O}_{2}$. During the determination of ligninase activity was used $2 \%$ veratryl alcohol. During determining the acellular and intracellular activity of enzymes were used the approach used in our previous work.

During the determination of fermentative activity, the amount of proteins was performed spectrophotometric way [16].

All experiments were performed in $4-6$ replicates and the obtained results were statistically processed [17]. In all cases, the results corresponding to the formula of $\mathrm{m} / \mathrm{M}=\mathrm{P} \leq 0.05$ were considered honest and included in the dissertation. Here, $\mathrm{M}-\mathrm{is}$ the average price of repetitions, $\mathrm{m}$-is mid-square dislocation mid-square displacement and $\mathrm{P}-$ is confidence level.

\section{The Results and Discussion}

To achieve the goals of the study were taken to the pure culture xylotrophic macromycetes that spreads in natural forest ecosystems located in different ecological areas of Azerbaijan and was created their collection. As a result, was created a collection from 103 strains which their characteristic by species specificity, area distribution, and substrate affiliation are shown in Table 1 . As see, the registered strains belong to 25 species of xylotrophic macromycetes but there is a certain difference with the ability to spread in ecologically different regions of Azerbaijan and substrate attitude. True, although most of them belong to evritropes, among of them are meets conditional stenotrophs.

In connection with the question about the table should be noted one issue. As seen, for the isolate of strains were used mainly from the fruit body of xylotrophic macromycetes cause white decay in natural conditions. The reason for this is characterized by the ability to the active realization of degradation of both cellulose and lignin in natural conditions of species xylotrophic macromycetes cause white decay. More specifically, due to the fact that both oxidases and hydrolases involved in their enzyme system, the strains needed for the research were separated from them.

From the studies conducted to assess the ability of the isolated strains to synthesize phenoloxidases became clear that, all of the tested strains have the ability to effectively synthesize the enzymes studied in this or that extent (Table 2), but they differ from each other by the level of activity. For example, if the activity of laccase, peroxidase, and ligninase in the mushroom Ganoderma applanatum $S$-17 was 70.6, 50.3 and $58.9 \mathrm{ui} / \mathrm{ml}$, respectively, the similar indication in the Lentinus tigrinus $F S-28$ was $60.5,45.3$ and $54.5 \mathrm{ui} / \mathrm{ml}$. Similar differences are also observed among other fungi.

Despite these differences, the activity calculated based on single biomass in mushrooms such as Cerena unicols, Pleurotus ostreatus, Schizophyllium commune and Trametes versicolor is higher than other mushrooms. For example, in Bjerkandera adusta P-40 $10.2 \mathrm{~g} / \mathrm{l}$, the activity of laccase, peroxidase and ligyninase is respectively $85.1 \mathrm{ui} / \mathrm{ml}, 62.2 \mathrm{ui} / \mathrm{ml}$ and $58.3 \mathrm{ui} / \mathrm{ml}$. The unit of enzyme 
Table 1. Species belonging spreads area and substrate relations of strains taken to the pure culture.

\begin{tabular}{|c|c|c|c|}
\hline № & $\begin{array}{l}\text { Fungi species which was } \\
\text { isolated strains }\end{array}$ & $\begin{array}{l}\text { The number of } \\
\text { isolated strains }\end{array}$ & $\begin{array}{l}\text { Geomorphological units in which the } \\
\text { species spread and relation to the substrate }\end{array}$ \\
\hline 1 & Armillaria mellea & 4 & GC, SC, TM, eurytrophy \\
\hline 2 & Bjerkandera adusta & 5 & GC, SC, TM, eurytrophy \\
\hline 3 & Cerena unicolar & 5 & GC, SC, TM, eurytrophy \\
\hline 4 & Daedalea quersina & 3 & GC, SC, TM, conditionally stenotroph \\
\hline 5 & Daedaleopsis confragosa & 3 & GC, SC, TM, conditionally stenotroph \\
\hline 6 & Flamulinna velutipes & 3 & GC, SC, TM, conditionally stenotroph \\
\hline 7 & Fomes fomentarius & 5 & GC, SC, TM, KA, eurytrophy \\
\hline 8 & Ganoderma applanatum & 5 & GC, SC, TM, KA, eurytrophy \\
\hline 9 & G.lucidum & 4 & GC, TM, eurytrophy \\
\hline 10 & Heteroporus pergamenus & 3 & GC, SC, TM, KA, eurytrophy \\
\hline 11 & Lentinus strigosus & 4 & GC, SC, TM, eurytrophy \\
\hline 12 & L.tigrinus & 3 & GC, SC, TM, eurytrophy \\
\hline 13 & Lenzitez betulina & 4 & GC, SC, TM, eurytrophy \\
\hline 14 & Phellinus igniarus & 5 & GC, SC, TM, KA, eurytrophy \\
\hline 15 & Ph.pomaceus & 4 & GC,SC,TM,KA, conditionally stenotroph \\
\hline 16 & Ph.torulosus & 3 & GQ, TM, şərti stenotrof \\
\hline 17 & Pycnoporus cinnabarinus & 3 & GC, TM, eurytrophy \\
\hline 18 & Pleurotus ostreatus & 5 & GC, SC, TM, KA, eurytrophy \\
\hline 19 & Polyporus suqamozus & 5 & GC, SC, TM, eurytrophy \\
\hline 20 & Pseudotrametes gibbosa & 5 & GC, SC, TM, eurytrophy \\
\hline 21 & Schizophyllium commune & 5 & GC, SC, TM, KA, eurytrophy \\
\hline 22 & Stereum gausapatum & 3 & GC, TM, conditionally stenotroph \\
\hline 23 & St.hirsitum & 4 & GC, SC, TM, KA, eurytrophy \\
\hline 24 & Trametes hirsuta & 5 & GC, SC, TM, KA, eurytrophy \\
\hline 25 & T.versicolor & 5 & GC, SC, TM, KA, eurytrophy \\
\hline
\end{tabular}

Note: GC-Greater Caucasus; KA-Kura Araz lowland; TM-Talish Mountains and SG—Small Caucasus.

activity in $1 \mathrm{~g}$ of biomass is respectively $8.34 \mathrm{ui} / \mathrm{ml}, 6.10 \mathrm{ui} / \mathrm{ml}$ and 5.72 times. The analogous indicator for T.versicolor $R-24$ is $9.47 \mathrm{ui} / \mathrm{ml}, 6.45 \mathrm{ui} / \mathrm{ml}$ and 8.65 $\mathrm{ui} / \mathrm{ml}$. For this reason, they were selected as active producers for further research. Interestingly, all these noted mushrooms are closely related to ecological-trophic relationships and are characterized mainly as polytrophc. More intensively the synthesis of phenoloxidase by polytrophic mushroom may be related with one of the indicators of their high adaptability.

From the carried out of research related to defining factors affect to the enzyme synthesis in selected strains, first of all, to clarify the impact of the carbon source, became clear that studied phenoloxidases by nature of synthesis carry the 
Table 2. Evaluation of the strains used in the studies by the oxidase activity (iu/ml).

\begin{tabular}{|c|c|c|c|c|c|}
\hline & $\begin{array}{l}\text { Fungi species which was } \\
\text { isolated strains }\end{array}$ & Biomass $\mathrm{q} / 1$ & Laccase & Peroxidase & Ligninase \\
\hline 1 & Armillaria mellea & $6.8-9.7$ & $62.2-71.2$ & $45.7-51.3$ & $50.2-56.2$ \\
\hline 2 & Bjerkandera adusta & $8.2-10.2$ & $75.8-85.1$ & $50.3-62.2$ & $54.8-58.3$ \\
\hline 3 & Cerrena unicolar & $8.8-10.1$ & $87.7-98.6$ & $55.8-66.3$ & $59.8-68.9$ \\
\hline 4 & Daedalea quersina & $7.7-9.2$ & $66.0-75.1$ & $45.3-50.8$ & $53.7-60.4$ \\
\hline 5 & Daedaleopsis confragosa & $6.7-7.4$ & $65.4-78.6$ & $46.8-54.3$ & $49.2-57.3$ \\
\hline 6 & Flamulinna velutipes & $8.1-9.1$ & $58.1-68.3$ & $37.0-48.3$ & $45.7-59.6$ \\
\hline 7 & Fomes fomentarius & $8.7-10.4$ & $64.2-84.9$ & $45.5-59.3$ & $63.8-84.8$ \\
\hline 8 & Ganoderma applanatum & $6.9-9.3$ & $62.2-70.6$ & $47.1-53.3$ & $52.1-60.6$ \\
\hline 9 & G.lucidum & $7.5-8.6$ & $56.2-65.1$ & $32.0-45.9$ & $40.9-56.7$ \\
\hline 10 & Heteroporus pergamenus & $7.7-9.2$ & $57.1-64.5$ & $32.4-43.3$ & $40.8-55.1$ \\
\hline 11 & Lentinus strigosus & $7.9-9.1$ & $53.2-65.3$ & $32.1-48.9$ & $41.1-55.7$ \\
\hline 12 & L.tigrinus & $6.9-8.8$ & $57.8-64.5$ & $42.5-50.3$ & $52.5-56.5$ \\
\hline 13 & Lenzitez betulina & $5.5-7.7$ & $54.3-64.3$ & $31.5-47.2$ & $39.9-58.3$ \\
\hline 14 & Phellinus igniarus & $6.1-7.8$ & $54.0-66.4$ & $34.6-47.5$ & $40.3-55.4$ \\
\hline 15 & Ph.pomaceus & $7.1-8.1$ & $51.9-60.5$ & $30.9-47.2$ & $39.8-58.7$ \\
\hline 16 & Ph.torulosus & $7.0-9.1$ & $53.2-64.2$ & $32.1-46.2$ & $40,9-55.9$ \\
\hline 17 & Pycnoporus cinnabarinus & $5.1-6.1$ & $51.2-62.3$ & $30.5-45.4$ & $39.3-57.4$ \\
\hline 18 & Pleurotus ostreatus & $7.8-9.5$ & $84.5-94.1$ & $50.3-64.2$ & $47.5-67.1$ \\
\hline 19 & Polyporus suqamozus & $6.8-8.9$ & $72.7-80.6$ & $41.8-50.3$ & $50.3-58.1$ \\
\hline 20 & Pseudotrametes gibbosa & $8.6-9.8$ & $63.2-85.4$ & $46.5-58.3$ & $60.7-73.5$ \\
\hline 21 & Schizophyllium commune & $7.4-8.8$ & $78.4-92.8$ & $50.8-60.3$ & $60.2-79.5$ \\
\hline 22 & Stereum gausapatum & $7.6-8.9$ & $60.2-67.5$ & $38.9-44.7$ & $43.5-49.5$ \\
\hline 23 & St.hirsitum & $7.2-9.0$ & $58.2-69.8$ & $35.8-47.7$ & $44.3-47.9$ \\
\hline 24 & Trametes hirsuta & $8.3-10.2$ & $74.2-90.2$ & $50.2-62.3$ & $67.3-78.3$ \\
\hline 25 & T.versicolor & $8.7-10.1$ & $77.1-95.6$ & $58.9-65.1$ & $63.1-88.2$ \\
\hline
\end{tabular}

Note: iu-International unit.

feature of inductive enzymes. So that, inclusion to the medium compounds holding in the composition lignin formed connections, but are characterized by relatively small degrees of polymerization is causes to raise the activity of all three enzymes this or that degree, which is clearly seen to the data given in the example of mushroom Sch.commune S-21 (Table 3). Compared with control, adding as the only carbon source to the medium of several substrates (Wood scrap, clean lignin, cornhorse, etc.) containing lignin in all the cases it leads to an increase in the overall activity of all three enzymes (total acellular and intracellular activity), which is inherent to inductive enzymes [18]. However, this process has slightly different shades than the synthesis of classic inductive enzymes. Thus, by adding any carbon source to the nutrient medium, meets 
Table 3. The impact of carbon sours on the synthesis of phenoloxidases in the active producers.

\begin{tabular}{ccccccc}
\hline \multirow{2}{*}{ Carbon sources } & \multicolumn{2}{c}{ Laccase } & \multicolumn{2}{c}{ Peroxidase } & \multicolumn{2}{c}{ Ligninase } \\
\cline { 2 - 7 } & $\mathbf{A}^{1}$ & $\mathbf{B}^{2}$ & $\mathbf{A}$ & $\mathbf{B}$ & $\mathbf{A}$ & B \\
\hline & \multicolumn{2}{c}{ Cerena unicolar M-16 } & & & \\
\hline Hidroxinon & 22.1 & 14.5 & 10.8 & 7.5 & 19.5 & 14.4 \\
Wood crumbs & 32.3 & 19.5 & 15.0 & 10.7 & 23.5 & 17.4 \\
Lignin (isolated from rye plant) & 43.0 & 28.5 & 24.6 & 14.4 & 32.4 & 22.5 \\
Lignin (isolated from ordinary pine) & 30.0 & 20.5 & 15.4 & 8.4 & 23.2 & 14.7 \\
Cornhorse & 49.4 & 36.4 & 32.9 & 18.7 & 35.1 & 25.1 \\
Wheat bran & 54.3 & 43.7 & 32.3 & 19.5 & 40.1 & 27.8 \\
Mannit & 44.8 & 30.4 & 27.8 & 16.5 & 19.7 & 12.3 \\
Corn extract & 47.5 & 32.1 & 22.4 & 13.7 & 34.7 & 24.1 \\
Saccharose & 18.2 & 10.1 & 8.9 & 5.4 & 7.0 & 5.0 \\
Glucose (control) & 17.2 & 9.6 & 8.2 & 5.1 & 6.0 & 4.2 \\
\hline
\end{tabular}

Note: A—intracellular activity; B-extracellular activity.

with the activity of enzymes. If always observed those activities consider as basal level inherent to inductive enzymes, then the basal level in xylotroph micromycetes is not in the amount to be determined by force as in classical inductive enzymes. That is, in xylotroph micromycetes, inductive synthesis has its own shades, which in our opinion, is due to their adaptability to living in woody substrates. More precisely, xylotrophic macromycetes have gained the character presence of an enzyme that initially initiates the degradation of the lignocellulose complex in the enzyme system and is secreted out of the cell. Since those situation has been observed in other mushrooms it can be noted as a feature peculiar to xylotrophic macromycetes.

\section{Conclusion}

Thus, from the carried out of research became clear that white decay cause species of xylotrophic macromycetes spread in the ecologically different regions of Azerbaijan can actively synthesize the phenoloxidases involved in the degradation of lignin which finds its highest point in the strains of Cerena unicolar, Pleurotus ostreatus, Schizophyllium commune and Trametes versicolor. While synthesis of phenoloxidases occurs in an inductive way, in contrast to classic inductive enzymes, in basidiomycetes basal levels are significantly higher which can be characterized as a sign to adaptation living in woody substrates in xylotrophic macromycetes.

\section{Conflicts of Interest}

The authors declare no conflicts of interest regarding the publication of this paper. 


\section{References}

[1] Das, A., et al. (2013) The Study on Regulation of Growth and Biosynthesis of Cellulolytic Enzymes from Newly Isolated Aspergillus fumigatus ABK9. Polish Journal of Microbiology, 62, 31-43.

[2] Sharma, A., Aggarwal, N.K. and Yadav, A. (2017) Isolation and Screening of Lignolytic Fungi from Various Ecological Niches. Universal Journal of Microbiology Research, 5, 25-34.

[3] Fedorova, T.V., Shakhova, N.V., Klein, O.I., Glazunova, O.A., Maloshenok, L.G., et al. (2013) Comparative Analysis of the Ligninolytic Potential of Basidiomycetes Belonging to Different Taxonomic and Ecological Groups. Applied Biochemistry and Microbiology, 49, 570-580. https://doi.org/10.1134/S0003683813060082

[4] Hasanova, A.R. (2016) Eco-Physiological and Biotechnological Aspects of Potential of Fungi Polyporaceae, as Producers of Oxidoreductases and Polysaccharides. Ph.D. Dissertation, Baku, Azerbaijan, 23.

[5] Stalpers, J.A. (1978) Identification of Wood-Inhabiting Aphyllophorales in Pure Culture. Stadies in Micology, 16, 248.

[6] Janusz, G., Kucharzyk, K.H., Pawlik, A., Staszczak, M. and Paszczynski, A.J. (2013) Fungal Laccase, Manganese Peroxidase and Lignin Peroxidase: Gene Expression and Regulation. Enzyme and Microbial Technology, 52, 1-12.

[7] Kadimaliev, D.A. (2011) The Participation of Laccase and Peroxidase of the Fungus Lentinus (Panus) Tigrinus in the Biodegradation of High Concentrations of Phenol in Liquid Media. Applied Biochemistry and Microbiology, 47, 73-78.

[8] Ilyin, D.Y. and Ilyina, G.V. (2014) Ecology of Xylotrophic Basidiomycetes in Nature and Pure Culture. RIO PGSA, Penza, 201.

[9] Kües, U. (2015) Fungal Enzymes for Environmental Management. Current Opinion in Biotechnology, 33, 268-278. https://doi.org/10.1016/j.copbio.2015.03.006

[10] Ruchai, N.S. and Grebenchikova, I.A. (2014) Microbial Synthesis Technology. Belarusian State Technological University, Minsk, Belarus, 167.

[11] Khacheva, S.I. (2015) Paths of Mycogenic Decomposition of Wood in Forest Ecosystems of Specially Protected Natural Territories of the Republic of Abkhazia. Scientific Notes of Kazan University, 157, 75-89.

[12] Aliyev, F.T. (2017) Scientific-Practical Aspects to Use Fungi of Genus of Trametes Quel., as a Producers of Polysaccharides. Ph.D. Dissertation, Baku, Azerbaijan, 23.

[13] Gahramanova, F.K., Hasanova, V.Y., Ragimova, M.M., Muradov, P.Z. and Hasanova, A.R. (2014) The Role of Some Phenoloxidases in the Decomposition of the Lignin Component of Cellulose-Containing Substrates. Scientific Papers Fundamental and Applied Problems of Science, M: RAS, 124-130.

[14] Bernicchia, A. (2005) Polyporaceae s. Fungi Europaei, 10, 808.

[15] Rodríguez-Couto, S. (2017) Industrial and Environmental Applications of White-Rot Fungi. Mycosphere, 8, 456-466. https://doi.org/10.5943/mycosphere/8/3/7

[16] Vrsanska, M., Voberkova, S., Langer, V., Palovcikova, D., Moulick, A., et al. (2016) Induction of Laccase, Lignin Peroxidase and Manganese Peroxidase Activities in White-Rot Fungi Using Copper Complexes. Molecules, 21, 1553. https://doi.org/10.3390/molecules21111553

[17] Kobzar, A.I. (2006) Applied Mathematical Statistics for Engineers and Academic Research. M.: Fizmatlit, 816. 
[18] Lundell, T.K., Mäkelä, M.R. and Hildén, K. (2010) Lignin-Modifying Enzymes in Filamentous Basidiomycetes-Ecological, Functional and Phylogenetic Review. Journal of Basic Microbiology, 50, 5-20. https://doi.org/10.1002/jobm.200900338 